\title{
Human parvovirus B19-induced aplastic crisis in an adult patient with hereditary spherocytosis: a case report and review of the literature
}

\author{
Yujin Kobayashi ${ }^{1,2^{*}}$, Yoshihiro Hatta ${ }^{1}$, Yusaku Ishiwatari ${ }^{2}$, Hitoshi Kanno ${ }^{3}$ and Masami Takei ${ }^{1}$
}

\begin{abstract}
Background: Although there are several case reports of human parvovirus B19 infection in patients with hereditary spherocytosis, no systematic reviews of adult patients with hereditary spherocytosis with human parvovirus B19 infection have been published as clinical case reports. In this study, we report a case of aplastic crisis due to human parvovirus B19 infection in an adult patient with hereditary spherocytosis.

Case presentation: A 33-year-old woman with hereditary spherocytosis and gallstones was admitted because of rapid progress in marked anemia and fever. Although empiric antibiotic therapy was prescribed, her clinical symptoms and liver function test worsened. Because the anti-human parvovirus B19 antibody and deoxyribonucleic acid levels assessed by polymerase chain reaction were positive, the patient was diagnosed with aplastic crisis due to the human parvovirus B19 infection.

Conclusion: We collected and reviewed several case reports of patients with hereditary spherocytosis aged $>18$ years with human parvovirus B19 infection between 1984 and 2010. A total of 19 reports with 22 cases [median age, 28 years (range, 18-43 range); male: female ratio, 6:16], including the present case were identified. The male-to-female ratio of 6:16 implied that younger females were predominantly affected. Although fever and abdominal symptoms were common initial symptoms, liver dysfunction or skin eruptions were less commonly documented. Anti-human parvovirus B19 antibody or deoxyribonucleic acid levels assessed by polymerase chain reaction was commonly used to diagnose human parvovirus B19 infection and may be useful to distinguish human parvovirus B19 infection from other abdominal infection in patients with hereditary spherocytosis.
\end{abstract}

Keywords: Hereditary spherocytosis, Human parvovirus B19, Aplastic crisis

\section{Background}

Human parvovirus (HPV)-B19 infection can cause aplastic crisis in a patient with hereditary spherocytosis (HS) associated with chronic hemolysis [1]. Although there are several case reports of HPV-B19 infection in patients with HS, particularly in children, no reports have reviewed this infection in a series of adult patients. In this study, we report a case of HPV-B19 infection-induced aplastic crisis in an adult patient. In addition to this case, we reviewed several adult patients with HPV-B19 infection and HS.

\footnotetext{
* Correspondence: eumagene@gmail.com

'Department of Hematology and Rheumatology, Nihon University School of Medicine, 30-1 Oyaguchi-Kamicho, Itabashi-ku, Tokyo 173-8610, Japan

${ }^{2}$ Division of Internal Medicine, Itabashi Medical Association Hospital, 3-12-6

Takashimadaira, Itabashi-ku, Tokyo 175-0082, Japan

Full list of author information is available at the end of the article
}

\section{Case presentation}

A 33-year-old woman was transferred to our hospital because of fever, general fatigue, nausea, and progressive anemia. The patient's condition was normal until 1 week before admission, when she experienced flu-like symptoms such as fever, general fatigue, and abdominal discomfort. The patient was diagnosed with HS at the age of 6 in another hospital by the presence of hemolytic anemia, spherocytosis, increased fragility of spherocytes by osmotic fragility testing, and the absence of antibodies by direct or indirect Coombs test. Asymptomatic gallstones were diagnosed at the age of 19 . The patient had undergone her annual blood test examination, and her hemoglobin concentration was maintained at approximately $10-12 \mathrm{~g} / \mathrm{dl}$. The patient was not under routine medications. Neither her parents nor her siblings 
had a history of HS. On admission, vital signs were as follows: blood pressure, 108/56 $\mathrm{mmHg}$; pulse rate, 100 beats/min; body temperature, $39.0^{\circ} \mathrm{C}$; and respiration rate, 12 breaths/min. While breathing ambient air, the patient's oxygen saturation rate was $100 \%$. On examination, she was alert, the skin and conjunctivae were pale, and the enlarged spleen was palpable from the costal margin. No skin rash or lymphadenopathy was observed; other physical findings were normal. The results of laboratory tests were as follows: white blood cell count was $2.97 \times 10^{9} / 1$ (granulocytes, 35\%; lymphocytes, $44 \%$; atypical lymphocytes, $9 \%$; and monocytes, $12 \%$ ), red blood cell count was $1.68 \times 10^{12} / \mathrm{l}$; hemoglobin concentration was $5.4 \mathrm{~g} / \mathrm{dl}$; hematocrit was $14.4 \%$; mean corpuscular volume was $86 \mathrm{fl}$; mean corpuscular hemoglobin was 32.1 pg; mean corpuscular hemoglobin concentration was $37.5 \%$; and platelet count was $84 \times 10^{9} / 1$. Reticulocytes decreased to $0 \%$. Spherocytosis was present on the peripheral blood smear. Liver function tests revealed levels of aspartate transaminase (AST) of $39 \mathrm{IU} / \mathrm{l}$, alanine aminotransferase (ALT) of $31 \mathrm{IU} / \mathrm{l}$, lactate dehydrogenase (LDH) of $342 \mathrm{IU} / \mathrm{l}$, alkaline phosphatase (ALP) of 144 IU/l, $\gamma$-glutamyl transpeptidase $(\gamma-\mathrm{GT})$ of $23 \mathrm{IU} / \mathrm{l}$, total bilirubin of $2.9 \mathrm{mg} / \mathrm{dl}$, and direct bilirubin of $1.0 \mathrm{mg} / \mathrm{dl}$. Hepatitis B virus surface antigen and anti-hepatitis $C$ virus antibody were negative. Haptoglobin concentration decreased to $2 \mathrm{mg} / \mathrm{dl}$, and the direct antiglobulin test was negative. Phosphatidylinositol glycan deficient clone was ruled out by flow cytometry. In addition to the past history, the presence of spherocytes on the peripheral blood smear, and the presence of gallstones, the definite diagnosis of HS was made with lower fluorescence of eosin-5-maleimide (EMA)-stained red blood cells due to the decreased amount of target proteins by a flow cytometry-based test (EMA binding test) [2] and shortened the acidified glycerol lysis test (AGLT) value [3] after admission. Because of high fever, history of gallstones, and the presence of pancytopenia, empiric administration of antibiotics was initiated for possible abdominal infection. The patient received two units of packed red blood cell and showed marked clinical improvement. On the 7th hospital day, fever relapsed and gastrointestinal symptoms (abdominal discomfort and nausea) worsened. Liver function tests showed levels of AST as $492 \mathrm{IU} / \mathrm{l}$, ALT as $320 \mathrm{IU} / \mathrm{l}$, LDH as $517 \mathrm{IU} / \mathrm{l}$, ALP as $351 \mathrm{IU} / \mathrm{l}, \gamma-\mathrm{GT}$ as $166 \mathrm{IU} / \mathrm{l}$, total bilirubin as $2.1 \mathrm{mg} / \mathrm{dl}$, and direct bilirubin as $1.0 \mathrm{mg} / \mathrm{dl}$. Computed tomography of the abdomen showed splenomegaly and gallstones, without hepatobiliary tract infection. Magnetic resonance cholangiography revealed no evidence of choledocholithiasis; blood cultures were negative. The results of anti-HPV immunoglobulin M (IgM) and immunoglobulin G (IgG) measured at admission were both positive, and HPV-B19 deoxyribonucleic acid (DNA) increased to $10^{5} \mathrm{copy} / \mathrm{ml}$ by quantitative real-time polymerase chain reaction (PCR) using the patient's peripheral blood. Thus, HPV-B19-induced aplastic crisis was diagnosed. Because of rapid recovery of hematopoiesis and clear evidence of HPV infection, bone marrow aspiration was not performed during admission. Liver function tests returned to normal without treatment. On the 14th hospital day, the patient was discharged without any symptoms, and the hemoglobin concentration elevated to $8.9 \mathrm{~g} / \mathrm{dl}$ (Figure 1 ).

We systematically reviewed the case reports of HPVB19 infection that occurred in adult patients with HS and conducted a literature search using the "Pubmed" search engine. The following terms "hereditary spherocytosis" and "parvovirus B19" were used to identify the appropriate peer-reviewed, English-language papers. We collected cases of adults, defined as patients over 18 years of age, and excluded pediatric cases. In addition to the present case, we reviewed all these cases, collected clinical information described in these articles, if written, and discussed the outcome. Between 1984 and 2010, a total of 19 reports with 22 cases, including the present case were identified [4-21]. Patients' characteristics, including those of the present case, are summarized in Table 1. Family history of HS was detected in 13 cases. Fever and liver dysfunction was documented in 18 and 4 cases, respectively. Skin manifestation was documented in only 2 cases. HPV-B19 infection was diagnosed through detection of anti-HPV B19 antibody in 12 cases, HPV-B19 DNA using PCR in 1 case, both antibody and PCR in 7 cases, and others in 2 cases.

\section{Discussion}

In this study, we presented a case of HPV-B19-induced aplastic crisis in an adult patient with HS, and we performed a review of clinical features of previously published cases. The results of our review showed that all patients were young, aged 18-43 years. Retrospective studies of immunocompetent subjects infected with parvovirus B19 showed that affected patients were relatively young; in one

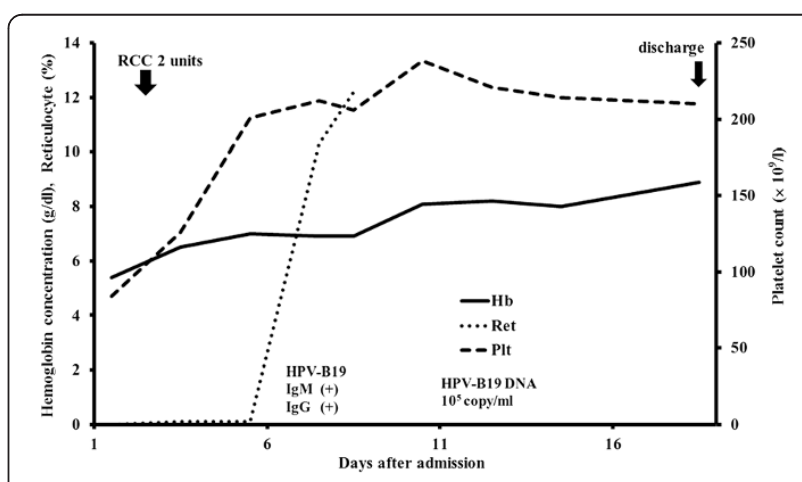

Figure 1 Clinical course of the patient. Abbreviations; RCC- Red Cell Concentrates, HPV-human parvovirus, Hb- hemoglobin, Ret- reticulocyte, Plt- platelet. 
Table 1 Clinical characteristics of 22 cases with human parvovirus B19 (HPV-B19) infection in adult patients with hereditary spherocytosis

\begin{tabular}{|c|c|c|c|c|c|c|c|c|c|c|}
\hline Reference & Age & Gender & Initial symptom & $\begin{array}{l}\text { Family history } \\
\text { of HS }\end{array}$ & Fever & Splenomegaly & $\begin{array}{l}\text { Liver test } \\
\text { abnormality }\end{array}$ & $\begin{array}{c}\text { Skin } \\
\text { manifestation }\end{array}$ & Gallstone & $\begin{array}{l}\text { Detection of } \\
\text { HPV-B19 }\end{array}$ \\
\hline [4] & 33 & Female & $\begin{array}{l}\text { Fever, abdominal pain, swelling of the hands, } \\
\text { fatigue, headache, palpitations, dizziness }\end{array}$ & Yes & Yes & Yes & - & - & - & Antibody \\
\hline [4] & 28 & Male & $\begin{array}{l}\text { Lethargy, weakness, shivering, muscular pain, } \\
\text { headache, palpitation, dizziness }\end{array}$ & Yes & - & Yes & - & - & - & Antibody \\
\hline [5] & 27 & Male & $\begin{array}{l}\text { Fever, night sweat, shivers, stiffness, headache, } \\
\text { dry cough, dizziness }\end{array}$ & Yes & Yes & Yes & - & - & - & Antibody \\
\hline [6] & 27 & Male & Fever, headache, pain, sweating, cough & Yes & Yes & Yes & - & - & - & Antibody \\
\hline [6] & 37 & Female & Fever, headache, sore throat, pains, cough & - & Yes & Yes & - & - & - & Antibody \\
\hline [7] & 30 & Female & - & - & - & - & - & - & - & Antibody \\
\hline [8] & 43 & Female & Fever, headache, nausea, diarrhea & Yes & Yes & - & - & - & - & Antibody \\
\hline [9] & 34 & Female & $\begin{array}{l}\text { Fever, malaise, fatigue, palpitation, arthralgia, } \\
\text { headache, dizziness }\end{array}$ & Yes & Yes & Yes & Yes & Yes & - & Antibody \\
\hline [10] & 34 & Female & Fever, jaundice, anemia & Yes & Yes & Yes & - & - & - & Immunoelectrophoresis \\
\hline [11] & 18 & Male & Vomiting, fever, lethargy & Yes & Yes & - & - & - & - & $\begin{array}{l}\text { Antibody in situ } \\
\text { hybridization }\end{array}$ \\
\hline [12] & 23 & Female & $\begin{array}{l}\text { Low back pain, arthralgia, fever, nausea, vomiting, } \\
\text { diffuse abdominal pain }\end{array}$ & Yes & Yes & Yes & - & Yes & Yes & Antibody \\
\hline [13] & 36 & Female & Fever, myalgia, malaise & - & Yes & Yes & - & - & - & Antibody, PCR \\
\hline [14] & 19 & Male & Malaise, anorexia, night sweats & - & Yes & Yes & - & - & - & Antibody, PCR \\
\hline [15] & 27 & Female & Arthralgia, pharyngitis, cough, nausea, vomiting, diarrhea & Yes & - & Yes & - & - & - & PCR \\
\hline [16] & 22 & Female & Anemia, jaundice & - & - & Yes & - & - & - & Antibody \\
\hline [17] & 28 & Male & Leg pain, fatigue & - & Yes & - & - & - & Yes & Antibody \\
\hline [18] & 19 & Female & Fever, malaise, urinary frequency & Yes & Yes & Yes & - & - & Yes & Antibody, PCR \\
\hline [18] & 27 & Female & Fever, malaise, splenomegaly & Yes & Yes & Yes & - & - & - & Antibody, PCR \\
\hline [19] & 19 & Female & Nausea, vomiting, dyspnea, sever fatigue, anemia & Yes & Yes & - & Yes & - & Yes & Antibody, PCR \\
\hline [20] & 34 & Female & Presyncope, fever, myalgia & - & Yes & Yes & - & - & - & Antibody, PCR \\
\hline [21] & 34 & Female & Anemia, fever & - & Yes & Yes & Yes & - & Yes & Antibody \\
\hline Present case & 33 & Female & Fever, fatigue, nausea, anemia & - & Yes & Yes & Yes & - & Yes & Antibody, PCR \\
\hline
\end{tabular}

A hyphen shows that there is no evidence or no description of each characteristic on the article. $\mathrm{HS}$, hereditary spherocytosis; HPV, human parvovirus; PCR, polymerase chain reaction. 
report, the median patient age was 38 years, with $86.7 \%$ aged 26-45 years [22], while in another report [23], the median age was 32-43 years (average, 38.0 years) for males and 15-43 years (average, 34.2 years) for females. Most individuals are infected with HPV-B19 during their school years, and the percentage of those with measurable levels of B19-specific IgG increases with age. More than $70 \%$ adults have measurable levels of B19-specific IgG antibodies [24,25]. Permanent immunity from HPV may decrease the incidence of viral infection in older patients with HS.

These cases were more frequently reported in females than in males. In the epidemiologic study of HPV-B19 infection-induced aplastic crisis in 308 children with homozygous sickle cell disease, the number of infected patients did not differ between genders [26]. The analysis of HPV-B19-induced epidemic acute red cell aplasia in 26 patients, primarily in children with hereditary hemolytic anemia (including only 1 patient with HS), included 14 males and 12 females [27]. In contrast, in a retrospective study of 30 immunocompetent patients infected with parvovirus B19 in Kyoto, the male:female ratio was 4:26 (86.7\% were female) [22]. Another retrospective study of 21 healthy, adult patients with HPV-B19 infection included 4 males and 17 females [23]. In humans, the genetic background probably accounts for the different patterns of HPV-induced anemia, and host genes may regulate the outcome of HPV-B19-induced aplastic crisis [28]. One may speculate that a correlation exists between genetic differences and gender gap in association with susceptibility to HPV infection, although very little is known with regard to this field.

Fever, nonspecific flu-like symptoms [1], and abdominal symptoms such as nausea or vomiting, abdominal pain, and diarrhea may occur in patients with HPVB19-induced aplastic crisis [27]. Abdominal symptoms were also commonly observed in our review. In contrast, abnormal liver function test results during HPVB19 infection was documented in limited cases. In pediatric patients, elevated levels of hepatic aminotransferases may accompany the fifth disease, and parvovirus infection has been associated with severe but selflimited hepatitis [29]. However, parvovirus B19 could not be implicated in a large number of adult patients with acute or chronic hepatitis [1]. The precise incidence of liver enzyme dysfunction that occurs during HPV-B19 infection in adult patients with HS is uncertain; therefore, further investigation is required. In a clinical scenario, because the development of bilirubin gallstones is a common complication of HS with chronic hemolysis, HPV infection should be considered as a part of the differential diagnosis of hepatobiliary tract infection in patients with HS since fever, abdominal pain, and liver enzyme dysfunction will also occur with such infection.
Documentation of skin manifestation was less frequent and may be considered to have less diagnostic value for HPV infection in adults. Similar to the fifth disease [1], although the skin rash is a well-known symptom, it is less characteristic in adults. In the report including 22 children with sickle cell disease or HS, no skin rash was observed during parvovirus B19-induced aplastic crisis [30]. The pathogenesis of the HPV-B19 infection-induced rash remains unclear. Because it usually coincides with the production of measurable serum antibody, it is presumed to be at least partially immune mediated [31-33]. Different immune reactions according to age may be associated with the varying incidences of skin reaction; however, the precise reason remains unclear.

HPV-B19 infects erythroid progenitor cells and inhibits erythropoiesis, leading to acute erythroblastopenia and reticulocytopenia [34]. The bone marrow in patients with transient aplastic crisis is characterized by an absence of maturing erythroid precursors and presence of giant pronormoblasts [1]. Although giant pronormoblasts are suggestive of parvovirus B19 infection, they are not diagnostic of the disease $[21,24]$. Because of pancytopenia accompanied with a marked decrease in reticulocytes as well as a history of HS, it was natural to believe that the patient in the present case was suffering from aplastic crisis due to viral infection; therefore, we did not perform bone marrow aspiration. Bone marrow aspiration may not be routinely required when viral infection-induced aplastic crisis is highly suspected.

\section{Conclusion}

We report a case of aplastic crisis caused by HPV-B19 in an adult patient with HS. To the best of our knowledge, the current study is the first report that reviewed HPV-B19-induced aplastic crisis in several adult patients with HS. HPV-B19 infection-induced aplastic crisis is more common in young female patients with HS. Although fever or abdominal symptoms generally occur during HPV-B19 infection, skin manifestation may appear less commonly. It may be helpful to detect HPV-B19 infection by antibody or PCR methods to distinguish it from other infections, such as hepatobiliary infection due to gallstones, if suspected.

\section{Consent}

Written informed consent was obtained from the patient for publication of this case report and accompanying images. A copy of the written consent is available for review by the Editor-in-Chief of this journal.

\section{Competing interests}

The authors declare that they have no competing interests. 


\section{Authors' contributions}

YK was responsible for the clinical management of our patient and preparation or writing of the first draft of the manuscript. $\mathrm{YH}$ and HK reviewed the manuscript and prepared the final draft. YI, HK and MT made substantial contributions to the acquisition and interpretation of clinical data. All authors read and approved the final manuscript.

\section{Acknowledgements}

Ms. Miyako Kobayashi provided us technical support for medical writing.

\section{Author details}

${ }^{1}$ Department of Hematology and Rheumatology, Nihon University School of Medicine, 30-1 Oyaguchi-Kamicho, Itabashi-ku, Tokyo 173-8610, Japan. ${ }^{2}$ Division of Internal Medicine, Itabashi Medical Association Hospital, 3-12-6 Takashimadaira, Itabashi-ku, Tokyo 175-0082, Japan. ${ }^{3}$ Department of Transfusion Medicine and Cell Processing, Tokyo Women's Medical University, 8-1 Kawada-cho, Shinjuku-ku, Tokyo 162-8666, Japan.

Received: 1 October 2013 Accepted: 4 March 2014

Published: 11 March 2014

\section{Reference}

1. Young NS, Brown KE: Parvovirus B19. N Engl J Med 2004, 350:586-597.

2. King MJ, Behrens J, Rogers C, Flynn C, Greenwood D, Chambers K: Rapid flow cytometric test for the diagnosis of membrane cytoskeletonassociated haemolytic anaemia. Br J Haematol 2000, 111:924-933.

3. Zanella A, Izzo C, Rebulla P, Zanuso F, Perroni L, Sirchia G: Acidified glycerol lysis test: a screening test for spherocytosis. Br J Haematol 1980, 45:481-486.

4. Green DH, Bellingham AJ, Anderson MJ: Parvovirus infection in a family associated with aplastic crisis in an affected sibling pair with hereditary spherocytosis. J Clin Pathol 1984, 37:1144-1146.

5. Lefrere JJ, Courouce AM, Boucheix C, Chomienne C, Bernadou A, Soulier JP: Aplastic crisis and erythema infectiosum (fifth disease) revealing a hereditary spherocytosis in a familial human parvovirus infection. Nouv Rev Fr Hematol 1986, 28:7-9.

6. Lefrere JJ, Courouce AM, Girot R, Bertrand Y, Soulier JP: Six cases of hereditary spherocytosis revealed by human parvovirus infection. $\mathrm{Br} J$ Haematol 1986, 62:653-658.

7. Saunders PW, Reid MM, Cohen BJ: Human parvovirus induced cytopenias: a report of five cases. $\mathrm{Br} J$ Haematol 1986, 63:407-410.

8. Takahashi M, Koike T, Moriyama Y, Shibata A, Koike R, Sanada M, Tsukada T: Inhibition of erythropoiesis by human parvovirus-containing serum from a patient with hereditary spherocytosis in aplastic crisis. Scand J Haematol 1986, 37:118-124.

9. Nunoue T, Koike T, Koike R, Sanada M, Tsukada T, Mortimer PP, Cohen BJ: Infection with human parvovirus (B19), aplasia of the bone marrow and a rash in hereditary spherocytosis. J Infect 1987, 14:67-70.

10. Eriksson BM, Stromberg A, Kreuger A: Human parvovirus B19 infection with severe anemia affecting mother and son. Scand J Infect Dis 1988 20:335-337.

11. Cohen H, Walker H, Delhanty JD, Lucas SB, Huehns ER: Congenital spherocytosis, B19 parvovirus infection and inherited interstitial deletion of the short arm of chromosome 8. Br J Haematol 1991, 78:251-257.

12. Cutlip AC, Gross KM, Lewis MJ: Occult hereditary spherocytosis and human parvovirus infection. J Am Board Fam Pract 1991, 4:461-464.

13. Baurmann H, Schwarz TF, Oertel J, Serke S, Roggendorf M, Huhn D: Acute parvovirus B19 infection mimicking myelodysplastic syndrome of the bone marrow. Ann Hematol 1992, 64:43-45.

14. Muir K, Todd WT, Watson WH, Fitzsimons E: Viral-associated haemophagocytosis with parvovirus-B19-related pancytopenia. Lancet 1992, 339:1139-1140.

15. Catton MG, Thomas SM, Blacklock HA, Croxson MC: Hypoplastic crisis with persistent arthralgia and prolonged parvovirus B19 viraemia detected by polymerase chain reaction. Aust N Z J Med 1993, 23:216-217.

16. Rinn R, Chow WS, Pinkerton PH: Transient acquired myelodysplasia associated with parvovirus B19 infection in a patient with congenital spherocytosis. Am J Hematol 1995, 50:71-72.

17. Beland SS, Daniel GK, Menard JC, Miller NM: Aplastic crisis associated with parvovirus B19 in an adult with hereditary spherocytosis. J Ark Med SoC 1997, 94:163-164.
18. Goss GA, Szer J: Pancytopenia following infection with human parvovirus B19 as a presenting feature of hereditary spherocytosis in two siblings. Aust N Z J Med 1997, 27:86-87.

19. A 19-year-old woman with severe anemia. Am J Med 1998, 104:200-209.

20. Oh SE, Kim JH, Choi CH, Park KH, Jung JY, Park Y, Park MJ: An adult with aplastic crisis induced by human parvovirus B19 as an initial presentation of hereditary spherocytosis. Korean J Intern Med 2005, 20:96-99.

21. Carzavec D, Gacina P, Vasilj A, Katovic SK: Aplastic crisis induced by human parvovirus B19 as an initial presentation of hereditary spherocytosis. Coll Antropol 2010, 34:619-621.

22. Oiwa H, Shimada T, Hashimoto M, Kawaguchi A, Ueda T, Sugiyama E, Kamiya T: Clinical findings in parvovirus B19 infection in 30 adult patients in Kyoto. Mod Rheumatol 2011, 21:24-31.

23. Hayakawa $H$, Tara M, Niina K, Osame M: A clinical study of adult human parvovirus B19 infection. Intern Med 2002, 41:295-299.

24. Cohen BJ, Buckley MM: The prevalence of antibody to human parvovirus B19 in England and Wales. J Med Microbiol 1988, 25:151-153.

25. Kerr S, O'Keeffe G, Kilty C, Doyle S: Undenatured parvovirus B19 antigens are essential for the accurate detection of parvovirus B19 lgG. J Med Virol 1999, 57:179-185

26. Serjeant GR, Serjeant BE, Thomas PW, Anderson MJ, Patou G, Pattison JR: Human parvovirus infection in homozygous sickle cell disease. Lancet 1993, 341:1237-1240.

27. Saarinen UM, Chorba TL, Tattersall P, Young NS, Anderson L, Palmer E, Coccia PF: Human parvovirus B19-induced epidemic acute red cell aplasia in patients with hereditary hemolytic anemia. Blood 1986, 67:1411-1417.

28. Morinet F, Leruez-Ville M, Pillet S, Fichelson S: Concise review: anemia caused by viruses. Stem Cells 2011, 29:1656-1660.

29. Sokal EM, Melchior M, Cornu C, Vandenbroucke AT, Buts JP, Cohen BJ, Burtonboy G: Acute parvovirus B19 infection associated with fulminant hepatitis of favourable prognosis in young children. Lancet 1998, 352:1739-1741.

30. Kellermayer R, Faden H, Grossi M: Clinical presentation of parvovirus B19 infection in children with aplastic crisis. Pediatr Infect Dis J 2003, 22:1100-1101.

31. Anderson MJ, Higgins PG, Davis LR, Willman JS, Jones SE, Kidd IM, Pattison $J R$, Tyrrell DA: Experimental parvoviral infection in humans. J Infect Dis $1985,152: 257-265$

32. Schwarz TF, Wiersbitzky S, Pambor M: Case report: detection of parvovirus B19 in a skin biopsy of a patient with erythema infectiosum. J Med Virol 1994, 43:171-174.

33. Kurtzman G, Frickhofen N, Kimball J, Jenkins DW, Nienhuis AW, Young NS: Pure red-cell aplasia of 10 years' duration due to persistent parvovirus B19 infection and its cure with immunoglobulin therapy. N Engl J Med 1989, 321:519-523.

34. Mortimer PP, Humphries RK, Moore JG, Purcell RH, Young NS: A human parvovirus-like virus inhibits haematopoietic colony formation in vitro. Nature 1983, 302:426-429.

\section{doi:10.1186/1756-0500-7-137}

Cite this article as: Kobayashi et al:: Human parvovirus B19-induced aplastic crisis in an adult patient with hereditary spherocytosis: a case report and review of the literature. BMC Research Notes 2014 7:137.

\section{Submit your next manuscript to BioMed Central and take full advantage of:}

- Convenient online submission

- Thorough peer review

- No space constraints or color figure charges

- Immediate publication on acceptance

- Inclusion in PubMed, CAS, Scopus and Google Scholar

- Research which is freely available for redistribution 